\title{
Intertidal mussel reefs change the composition and size distribution of diatoms in the biofilm
}

\author{
Rosyta Andriana $^{1} \cdot$ Friederike G. Engel $^{2} \cdot$ Joao B. Gusmao ${ }^{3} \cdot$ Britas Klemens Eriksson $^{1}(\mathbb{C}$
}

Received: 26 June 2020 / Accepted: 30 December 2020 / Published online: 4 February 2021

(c) The Author(s) 2021

\begin{abstract}
Migrating diatoms are microscopic ecosystem engineering organisms that have functional consequences on the seascape scale by significantly contributing to the microphytobenthos biofilm. The microphytobenthos biofilm is a thin photosynthesising layer that covers the sediment on intertidal flats. It fuels the food web, increases sediment stability, and enhances the deposition of particles, providing ecosystem services to coastal communities. Here we tested the effect of another ecosystem engineering habitat, intertidal blue mussel reefs, on the composition and properties of migrating diatom communities. Smallscale reefs constructed in the intertidal mimicked and reinforced the natural pattern in diatom community composition and function that we documented in the field. The field experiment adding small reefs to the intertidal ran from 30 April to 10 June 2015 and the field samples were collected around a natural blue mussel bed on the same tidal flat on 7 October 2015 $\left(\mathrm{N} 53.489^{\circ}, \mathrm{E} 6.230^{\circ}\right.$ ). Both the constructed small-scale reefs and the natural reef changed the community composition of diatoms in the biofilm by promoting higher numbers of smaller-sized cells and species. Small diatoms have higher growth and gross photosynthesis rates, indicating that this explains the higher production and chlorophyll-a concentration of the biofilm measured on natural intertidal shellfish reefs. Our results showed that shellfish reefs have a large impact on biofilm functioning. However, biofilms are also fuel for the shellfish, indicating that the two very different ecosystem engineers may facilitate coexistence on tidal flats through a positive feedback loop.
\end{abstract}

\section{Introduction}

Marine soft sediment diatoms are microscopic ecosystem engineers that fundamentally alter the function of intertidal flats. They are characterised by two main groups of motile pennate raphid diatoms: epipelon, which is larger (length of $>10 \mu \mathrm{m}$ ) and moves freely in the muddy sediment, and

Responsible Editor: F. Bulleri.

Reviewed by undisclosed experts.

Britas Klemens Eriksson

b.d.h.k.eriksson@rug.nl

1 Marine Ecology, Groningen Institute for Evolutionary Life Sciences (GELIFES), University of Groningen, Groningen, The Netherlands

2 Department of Biology, University of Florida, Gainesville, USA

3 Millennium Nucleus for Ecology and Sustainable Management of Oceanic Islands (ESMOI), Facultad de Ciencias del Mar, Universidad Católica del Norte, Larrondo 1281, Coquimbo, Chile epipsammon with smaller size (length $<10 \mu \mathrm{m}$ ) that can be found closely associated with sandy grains (Barnet et al. 2015; Ribeiro et al. 2013). The intertidal diatom community is easily recognised through their significant contribution to a thin-brown photosynthesising layer, the biofilm, that forms on top of the sediment during low tide (Aleem 1950; Kromkamp and Foster 2006). The biofilm consists of a complex matrix of extracellular polymeric substances (EPS) that surrounds the biofilm-associated organisms. The EPS is produced in large quantities by motile diatoms and has an important ecosystem function by binding particles together; stabilising shallow sediment; and influencing sediment transport on the seascape scale (Grant et al. 1986; Vos et al. 1988; Paterson 1989; Hoagland et al. 1993; Malarkey et al. 2015).

Primary productivity of the biofilm on the intertidal flat is a result of hydrodynamic disturbance (regulating sediment erosion), sediment characteristics (organic matter content, grain size), the elevation of the tidal flat (influencing the photoperiod), species composition (influencing pigment composition and growth rates), and vertical migration of the benthic diatoms themselves (Heip et al. 
1995; De Jong and Jonge 1995; Paterson 1986). The diatom biofilm contributes to a significant part of the total primary production on intertidal flats and fuels the benthic food web by supporting higher trophic levels, including blue mussels, oysters, birds, and fish (Admiraal 1984; Underwood and Kromkamp 1999; Christianen et al. 2017).

Intertidal blue mussel reefs (Mytilus edulis L.) are themselves important ecosystem engineers that mitigate hydrodynamic disturbance, change sediment properties, and provide habitat for a variety of associated organisms across trophic levels (Widdows et al. 1998, Widdows and Brinsley 2002; Gutiérrez et al. 2003; van der Zee et al. 2012). The engineering effects of blue mussels manifest both within the reefs and on a larger scale; blue mussel reefs modify the surrounding up to several hundred meters across the tidal flat (Donadi et al. 2013a; van de Koppel et al. 2015). The mussels remove suspended particulate matter from the water column and deposit this as nutrientrich faeces and pseudofaeces (Biodeposit: Verwey 1952; Kautsky 1987; Asmus and Asmus 1991). Biodeposit from bivalves display elevated nutrient and chlorophyll $a$ concentrations, indicating that the enrichment of the sediment contributes to an increased diatom production (Giles and Pilditch 2006; Donadi et al. 2013b). In addition, shelter provided by intertidal blue mussel reefs can initiate the development of diatom films in areas where the energy is otherwise too high (Donadi et al. 2013b; Engel et al. 2017). When a biofilm starts to develop in an area, EPS accumulation of the surface of the sediment will bind smaller sediment particles and decrease the sediment erosion threshold, increasing diatom production and organic matter content (van de Koppel et al. 2008). Diatoms grow better in sediment with high organic matter content because of the correlation with low sediment erosion and high nutrient availability (Stal and Brouwer 2003). Van de Koppel et al. (2008) showed that diatoms exude EPS that stabilises the sediment, which further promotes diatom growth and even more EPS production, leading to a positive feedback that promotes a stable and productive biofilm. Similarly, bivalves are favoured by low sediment erosion because this promotes the settlement and establishment of their juveniles (Donadi et al. 2014; van de Koppel et al. 2015). Because of resuspension, the microphytobentos is also an important food-source for blue mussel reefs on tidal flats. Thus, while blue mussel reefs are fuelled by the biofilm, they also facilitate the biofilm, indicating that positive feedbacks between these very dissimilar ecosystem engineers may reinforce each other (Eriksson et al. 2010).

In this study, we tested the effect of intertidal blue mussel reefs on the biodiversity and composition of the migrating diatom community, to increase the understanding of the interaction between bioengineering of the mussels and the function of the biofilm. In earlier studies, we have observed that the production and chlorophyll- $a$ content of the biofilm increase on mussel reefs compared to bare areas on an intertidal flat (Engel et al. 2017). The size of diatoms (measured as biovolume) is inversely related to their growth rates and the chlorophyll- $a$ specific absorption coefficient, which is an important property determining gross photosynthesis rates (Geider et al. 1986; Morin et al. 2008). Small diatoms also have a relatively large surface to volume ratio, which allows them to absorb nutrients rapidly and compete successfully in nutrient rich environments (Geider et al. 1986). We therefore hypothesised that the increase in biofilm production observed on mussel reefs (Engel et al. 2017) relates to a shift in diatom community composition towards smaller species and a higher total biovolume caused by an increased number of cells. Changes in the growth rate, composition of species, and size distribution of the diatom community influence EPS production (Smith and Underwood 1998; Underwood and Smith 1998; Brouwer et al. 2005) and therefore should have consequences for the sediment stabilising function of the biofilm.

Intertidal blue mussel reefs often form large aggregations that span 100s of meters, and consist of a thick and elevated mussel matrix interspersed by smaller patches of bare substrate and water-filled pools. Since it is difficult to construct or manipulate such a complex and large structures as natural blue mussel beds in a realistic way, we instead created small plot-sized $\left(1 \mathrm{~m}^{2}\right)$ artificial mussel reefs to causally link the changes in the migrating diatom community to the presence of mussels. Since blue mussel reefs enrich the sediment and decrease sediment erosion, we hypothesised that the small-scale additions of mussels would promote local production and development of the biofilm: generating a biofilm with higher diatom biovolume, with higher diatom abundances, and with a higher fraction of smaller diatom species, compared to plots where we did not add mussels (e.g. Asmus and Asmus 1991; Geider et al. 1986; Giles and Pilditch 2006; Donadi et al. 2013a). However, the small-scale artificial reefs do not mimic the large-scale hydrodynamic effects and complexity of natural blue-mussels reefs (e.g. Donadi et al. 2013a). To make a realistic inference of the results, we therefore compared the results from the small-scale experiment with the natural species composition and size distribution of the migrating diatom community around a large intertidal shellfish reef. 


\section{Material and methods}

\section{Field experiment}

We conducted the field experiment on an intertidal flat in the Netherlands, south of the island of Schiermonnikoog (N 53.489 ${ }^{\circ}$, E $6.230^{\circ}$, Fig. S1). The intertidal flats in this area are characterised by vast stretches of bare sediment that are occasionally broken up by blue mussel reefs that can cover several hectares. In the past decade, the Pacific oyster (Crassostera gigas [Thunberg]) has increased strongly on the blue mussel reefs (Andriana et al. 2019). Today, the older parts of the reefs consist of a mixed matrix of oysters and blue mussels, while the younger parts are still completely dominated by blue mussels. Previous studies have shown that benthic habitat characteristics (e.g. sediment type) vary depending on proximity to shellfish reefs (Donadi et al. 2013a, b). We therefore replicated the experimental set-up in two sites with visibly different sediment character, one on the coastal side of the mussel reef (along field study transect MB, see field study below; site "wake") and one at the same tidal elevation in the sandy area adjacent to the reef (along field study transect S, see field study below; site "sand") (Fig. S1). The "wake" site was more sheltered, and the sediment type (mud/silt, high organic matter content; see results) had a characteristic of cohesive sediment (plaster erosion loss: $12.8 \pm 1.3 \%$ per tide, $n=4$; relative shear strength of the sediment: $7.5 \pm 2.7, n=7$; mean $\pm \mathrm{SD}$ ). The "sand" site was more exposed and had a sediment type characteristic of sandy less cohesive sediment (plaster erosion loss: $14.9 \pm 1.2 \%$ per tide, $n=4$; relative shear strength of the sediment: $2.5 \pm 2.2, n=7$; mean $\pm \mathrm{SD}$ ). Erosion was measured as weight loss of model plaster (Knauf Modelgips, Knauf B.V., Utrecht, The Netherlands) moulded in plastic cylinders $(6.3 \mathrm{~cm}$ long; $2.4 \mathrm{~cm}$ diameter $)$ with a pin through them. The pin was inserted in the sediment so that the plaster cylinders were fully exposed to the incoming water. The cylinders were left on the tidal flat for two tidal cycles and then dried in the laboratory until constant weight. We measured the undrained shear strength of the sediment using a handheld shear vane. A shear vane consists of a rod with vanes mounted to one end and a torque gauge in the other end. The vane is inserted in the sediment and slowly rotated until the cohesiveness of the sediment fails, so that the vane rotates in the sediment (Grabowski 2014). However, vanes are normally adapted for soil with high shear strength. We therefore used longer home-made and non-calibrated vanes in all our samplings, which are more suitable for softer intertidal sediment (pers comm Tjeerd Bouma, NIOZ). Thus, we did not transform the shear strength to an absolute unit. The measurements are therefore limited to show differences in relative cohesion between sites. The measurements were collected across the whole tidal flat on two different occasions in September and October by different persons. We, therefore, min-max normalised the data to be between 0 and 10 to make it comparable.

At each site, we constructed 15 experimental plots with an area of $0.25 \mathrm{~m}^{2}$ each (sides 0.5 by $0.5 \mathrm{~m}$ ), placed in three parallel rows with three meters between each of the plots (to all sides). To six randomly chosen plots at each site, we added live blue mussels (M. edulis) (treatment "reef"), while six other plots were left unaltered (treatment "bare flat"). Placing experiments on an intertidal flat may lead to critical artefacts because of changes to water flow caused by equipment rather than treatments, but also because of changed predation rates since the experiment may hinder or attract natural predators. Isolated clumps of blue mussels are highly prone both to crab and bird predation and may quickly be completely removed when placed on the tidal flat. We therefore protected the mussels by constructing two types of experimental controls with different effects on predation and exposure. Half of the plots in both the bare flat and reef treatments had a fence mounted around them consisting of a plastic net ("plastic fence"). The plastic net protects the mussels from both crab and bird predation but may have strong effects on flow. The other half of the plots had a fence consisting of a rope placed around the perimeter that only hinder birds from eating the mussels but have minimal effects on flow ("rope fence"). The ropes were fastened in a $66-\mathrm{cm}$ long plastic pole marking each corner of the plot, inserted $30 \mathrm{~cm}$ into the sediment. In the bare flat treatments, the same types of fences (cage and rope) were used, to have a comparable control to the mussel reef treatment. In addition, three plots at each site were left completely unmanipulated (no addition of mussels and no addition of a fence), to separately test for "fence" effects. We did this by comparing the effects of fence on the diatom community in the plots without mussel additions: thus comparing the "no mussel additions and no fence" treatment (unfenced control) with the "bare flat and plastic fence" and "bare flat and rope fence" treatments, respectively (see Supplement 2). The experiment was set out on the 30 April 2015. We sampled the sediment in the plots to analyse diatom abundance and species composition, chlorophyll- $a$ concentrations, and organic matter content, on the 10 June 2015 , approximately 1 month after the mussel addition and at the height of biofilm development. Diatom abundance as estimated by chlorophyll- $a$ concentrations in the sediment normally peaks in the month of June in the Wadden Sea (Staats et al. 2001; Van der Wal et al. 2010). For more details on the experimental set-up, see Engel et al. 2017. 


\section{Field study}

We performed the field study by setting up four parallel transects, spanning from the coast seaward, on the same intertidal flat as the field experiment (Fig. S1). The transects were $200 \mathrm{~m}$ apart from each other and $400 \mathrm{~m}$ long. One transect crossed an intertidal blue-mussel reef (transect MB), two transects crossed the flat $50 \mathrm{~m}$ on each side of the shellfish reef (transects ME and MW), and one transect crossed a bare part of the flat $250 \mathrm{~m}$ from the shellfish reef (transect S). Previous analyses demonstrate a small spatial variability among sampling points based on their physical locations in relation to the mussel bed (Engel et al. 2017). We therefore divided all sampling points into either "reef front": sites on the seaside close to the reef ( $50 \mathrm{~m}$ away; $n=3$ ); "reef wake": sites in the sheltered wake close to or on the reef (0-75 m; $n=4)$; or "bare sand": sites more than $100 \mathrm{~m}$ from the reef with visibly much sandier sediment than the sites closer to the reef $(n=10)$. We sampled sediment from each of the 17 transect points on the 7 October 2015; to analyse diatom abundance and species composition, chlorophyll- $a$ concentration, and organic matter content (for "Material and methods" see below).

\section{Sediment sampling and sample processing}

At each transect point and in each experimental plot, we took sediment cores (diameter: $26 \mathrm{~mm}$ ) for measuring chlorophyll- $a$ concentration and organic matter content in the sediment, as well as to determine benthic diatom composition and biomass. For chlorophyll- $a$ and species composition, we pooled the sediment from three cores of $0.2 \mathrm{~cm}$ (chlorophylla) and $2 \mathrm{~cm}$ (diatom composition) depth, respectively. The cores where sampled $1 \mathrm{dm}$ from each other in a triangular pattern, and the sediment was collected in a piece of aluminium foil to avoid exposure to light. Organic matter was sampled with a 5-cm-deep core (once in each plot/transect point). All samples were placed in sealed plastic bags and transported back to the laboratory on ice in a cool box.

Further sample processing took place in the laboratory. Chlorophyll- $a$ concentration was determined by a method derived from Jeffrey and Humphrey (1975): After freezedrying the sediment, we extracted the chlorophyll with $90 \%$ acetone (dark, $-20^{\circ} \mathrm{C}, 48 \mathrm{~h}$ ) and measured concentration with a fluorometer (Trilogy, Turner Design). We determined organic matter content of the sediment by Loss on Ignition (burning oven dried samples in a muffle kiln at $550{ }^{\circ} \mathrm{C}$ for $4 \mathrm{~h}$ ). For diatom species identification and biovolume calculation, the live motile benthic microalgae were extracted from the sediment by spreading out the sediment in petri dishes and placing two layers of lens cleaning tissue on top of the sediment. After $5 \mathrm{~h}$ of exposure to light, we removed the top layer of the tissues, which now contained the diatoms that migrated to the surface. We rinsed the diatoms off the tissues with sterile North Sea water and collected the communities in brown glass bottles. We fixed the samples with Lugol's iodine solution and stored them in the dark until further processing. To determine species composition and biovolume of the diatoms, we used the Utermöhl technique (Utermöhl 1958) and counted diatom cells under an inverted microscope $(400 \times$ magnification $)$. We identified diatom groups to the highest resolution possible, which for some diatoms was the genus level. We calculated species-specific biovolumes based on methods described by Hillebrand et al. (1999), which uses simple geometric shapes to approximate diatom cell volume by measuring multiple dimensions of several cells per species.

\section{Data analyses}

We analysed experimental effect on species composition based on both biovolume and cell numbers, using permutational multivariate analysis of variance (PERMANOVA) (analysing distance matrices using the adonis2 function in the vegan package, version 2.5-6; R Core Team 2020; Oksanen et al. 2019). We analysed experimental effect on total biovolume, total cell number, average cell size, and species richness of the diatom community, as well as organic matter content of the top $5 \mathrm{~cm}$ of the sediment using analysis of variance (ANOVA). All models contained the fixed explanatory factors mussel addition ("bare flat" or "mussel reef"), type of fence (plastic net or rope), and site (reef "wake" or "sand"). However, we lost two of the fenced replicates at the sandy site creating an unbalanced design. We therefore compared AICc values for the univariate models including different levels of interactions (full factorial model: site $\times$ fence $\times$ mussel addition; two-way factorial model: site $\times$ fence + fence $\times$ mussel addition + site $\times$ mussel addition; main effects model: site + fence + mussel addition) using ANOVA for unbalanced designs (Type III ANOVA using the car package in R, version 3.0-10). In the ANOVA analyses of total biovolume, total number of diatom cells, size distribution, and organic matter content, none of the interaction effects were statistically significant and the reduced model without any interactions was consistently the best model according to AICc (lowest AICc values; Table. S3). For all univariate models (ANOVAs), except for species richness, we therefore present results from the most reduced model (main effects model). For species richness, we present results from the two-way factorial model, which was the best model according to AICc (Table S3). If needed to fit assumptions of the models, data were sqrt- or logtransformed. We did not analyse experimental effects on chlorophyll- $a$ concentrations in the sediment, since these were analysed and presented for a larger subset in Engel et al. (2017). 
For the field study, the species composition based on biovolume data was analysed with Nonmetric Multidimensional Scaling (NMDS) using Bray Curtis dissimilarities (monoMDS in the vegan package, version 2.5-6; R Core Team 2020; Oksanen et al. 2019). We tested if there was a difference in community composition between different habitats ("reef front", "reef wake", or "sand") using analysis of similarities (ANOSIM; vegan package, version 2.5-6; R Core Team 2020; Oksanen et al. 2019). The relation between different covariates (total biovolume, cell numbers, average cell size and species richness of the diatom community, chlorophyll- $a$ concentration, and organic matter content of the sediment) and the species composition of the diatom community was evaluated using the envfit function, which correlates the covariates onto the ordination axes. To get a visualisation of changes in species composition, we also plotted the weighted averages for each species along the ordination axes, based on the biovolume at each site (species scores). We also tested differences in the covariates between different habitats ("reef front", "reef wake", or "sand") using one-way analysis of variance (ANOVA). If needed to fit assumptions of the models, data were sqrt- or log-transformed.

\section{Results}

\section{Field experiment}

The experimental blue mussel reefs changed the species composition and size distribution of motile diatoms in the biofilm (Fig. 1). The community included 22 species groups of motile diatoms (Table S4). There was a difference in diatom species composition between the plots with artificial mussel reefs compared to the plots without reefs ("bare flat"), and between the reef wake and sand plain habitats, both for the multivariate analyses based on biovolume and cell numbers (PERMANOVA; biovolume-mussel addition: $F_{1,14}=2.8, p=0.036$; site, $F_{1,14}=7.1, p<0.001$; cell number-mussel addition: $F_{1,14}=2.8, p=0.048$; site: $F_{1,14}=8.0<0.001 ;$ Fig. 1a, b). The change in community composition was mainly caused by the mussels promoting a higher number of diatoms with small cell sizes (biovolume $<51 \mu^{3}$; [CYL, NAV I\&II, NITZ I\&II]; Table S4; Fig. 1a, b). The PERMANOVAs showed no significant interaction effects $\left(F_{1,14}<1.5, p>0.17\right)$ and no significant effects of different types of fencing around the experimental plots (biovolume-fence: $F_{1,14}=1.6, p=0.18$; cell numberfence: $F_{1,14}=1.9, p=0.102$ ). In addition, there were no significant effects of the ropes or the plastic fence compared to the unmanipulated control ("fence" effects; Supplement 2).

The experimental reefs increased the total number of cells and decreased the average cell size of the diatoms
(ANOVA, main effect of mussel additions- total cell number: $F_{1,18}=4.6, p=0.046$; average cell size: $F_{1,18}=7.4$, $p=0.014$ ), but had no significant effects on total biovolume, organic matter content of the sediment, or species richness (ANOVA, main effect of mussel additions - total biovolume: $F_{1,18}=0.7, p=0.417$; organic matter content: $F_{1,18}=0.1$, $p=0.768$; species richness: $F_{1,18}=0.7, p=0.417$; Table S5, Fig. 1). The total biovolume, total cell numbers, organic matter content of the sediment, and species richness were higher in the wake of the mussel bed compared to the sand plain habitat (ANOVA, main effect of site-total biovolume: $F_{1,18}=11.1, p=0.004$; total cell number: $F_{1,18}=17.1$, $p<0.001$; organic matter content: $F_{1,18}=36.7, p<0.001$; species richness: $F_{1,18}=30.7, p<0.001 ;$ Fig. 1$)$. Site had no effect on average cell size (ANOVA: $F_{1,18}=0.8, p=0.373$ ). The type of fence only had significant effects on species richness (Table S5), where the plastic fence increased species richness in the more sheltered wake of the mussel bed (ANOVA, significant interaction effect between fence type and site: $F_{1,18}=11.0, p=0.005$ ). There were no significant "fence" effects on any of the response variables, comparing different fences to the unmanipulated control (Supplement 2).

\section{Field study}

We found a clear difference in the diatom community composition between the sand habitat, and the front and wake of the mussel reef (Fig. 2). According to the analysis of similarities (ANOSIM), the variation in species composition was statistically significantly different between different habitats ( $R=0.43, p=0.004$; Fig. 2a). Navicula spp. dominated the biofilm, but the reef front was additionally characterised by the largest species: $56 \%$ of the total biovolume consisted of species with a biovolume $>1300 \mu^{3}$ (Pleurosigma aestuarii, Entomoneis paludosa, Stauroneis spp., and the largest species of Navicula [NAF and NAA; Table S4; Figs. 2b, $3 a)$. The reef wake was characterised by high numbers of the smaller species: $57 \%$ of the counted individuals had a biovolume $<51 \mu \mathrm{m}^{3}$ (Cylindrotheca closterium, and the smallest species of Navicula [NAV I\&II] and Nitzschia [NITZ I\&II]; Figs. 2b, 3b). The sand communities were completely dominated by medium sized Navicula species: $92 \%$ of the biovolume (NAV III\&IV, Fig. 3a). There was a significant correlation between total biovolume, cell size, chlorophyll- $a$, organic matter content of the sediment, and species richness, and the composition of the diatom community along the ordination axes (Fig. 2a) (NDMS, envfit function results: total biovolume: $r^{2}=0.57, p=0.004$; cell size: $r^{2}=0.53, p=0.006$; chlorophyll- $a$ : $r^{2}=0.38, p=0.046$; organic matter: $r^{2}=0.41, p=0.031$; species richness: $r^{2}=0.67, p<0.001$; Fig. 2a). Statistical analyses of differences between habitats supported some of the apparent 


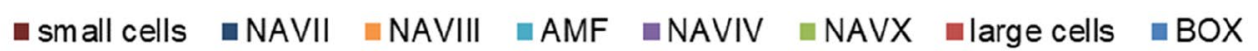
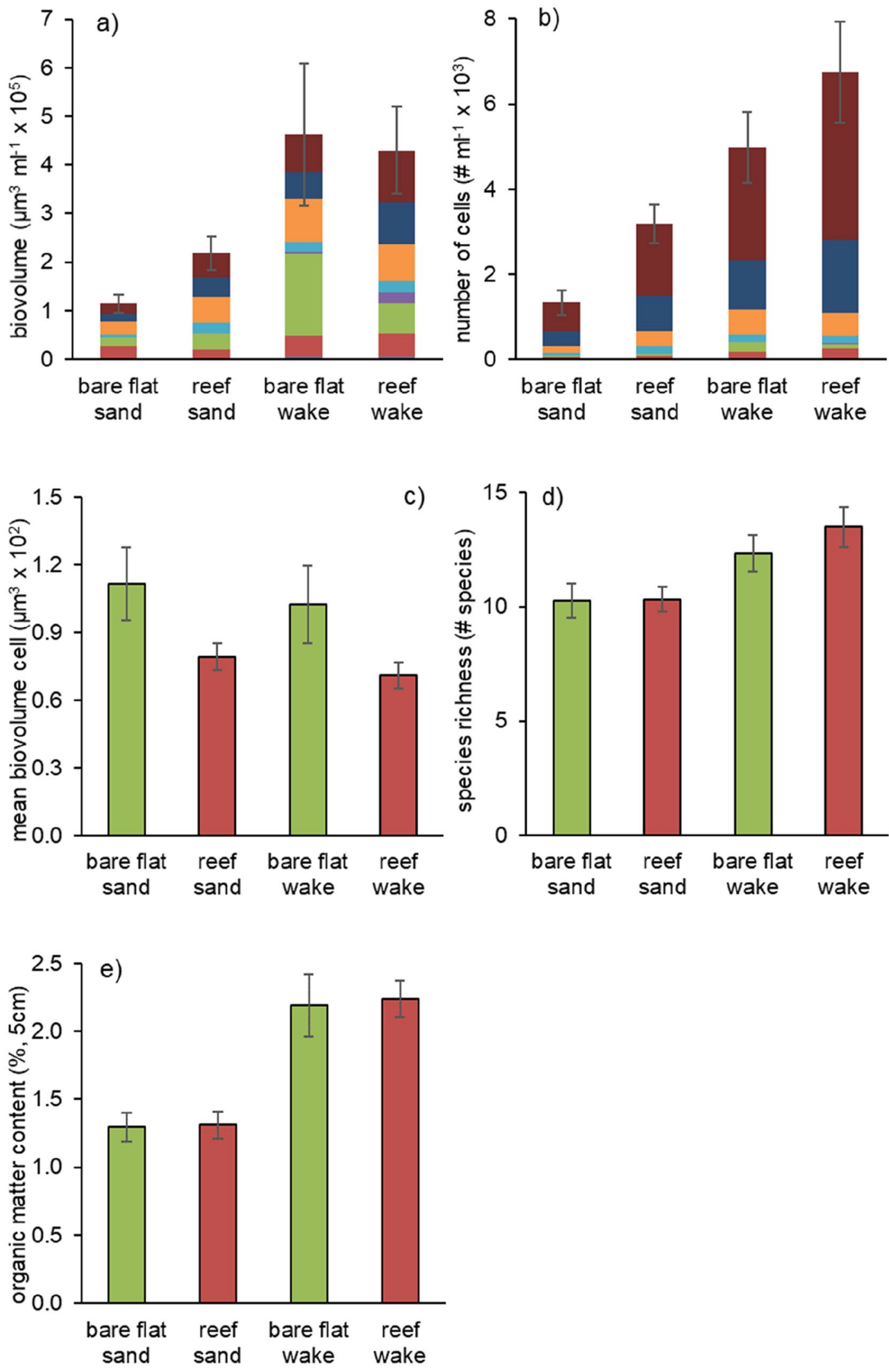
४Fig. 1 Experimental effects on diatom community composition and properties of the biofilm by adding small artificial mussel reefs to an intertidal flat (comparing reef vs bare flat), in an exposed sandy habitat (sand) and a more sheltered wake of a blue mussel reef (wake). a biovolume of diatoms, $\mathbf{b}$ number of diatom cells, $\mathbf{c}$ mean biovolume of the individual cells, $\mathbf{d}$ species richness of the diatom community, and $\mathbf{e}$ the organic matter content of the upper $5 \mathrm{~cm}$ of the sediment. Error bars show standard error of the mean; in $\mathbf{a}$ and $\mathbf{b}$ the bars show SE for the total biovolume and the sum of all diatom cells, respectively. The legend on the top rank the species left to right from smallest to largest size. For abbreviations of species names, see Table S4

relations in the NDMS plot: the average size of the diatom cells and total biovolume was highest in the mussel reef front; the species richness of the diatom film was higher in both reef affected habitats ("reef front" and "reef wake") compared to the sand flat; and there were no significant differences in total number of diatom cells between habitats (ANOVA: biovolume: $F_{2,14}=4.2, p=0.038$; cell number: $F_{2,14}=0.8, p=0.488$; cell size: $F_{2,14}=5.0, p=0.023$; species richness: $F_{2,14}=8.8, p=0.003$; Fig. 3). However, contrary to the expectations from the NMDS plot, there were also no significant differences between the habitats for the organic matter or chlorophyll- $a$ content of the sediment (ANOVA: chlorophyll- $a$ : $F_{2,14}=1.9, p=0.187$; organic matter content: $F_{2,14}=1.6, p=0.233$; Fig. 3 ).

\section{Discussion}

We show that mussel reefs can change species composition and the size distribution of the biofilm by promoting higher numbers of small motile diatoms. Constructing small mussel reefs increased diatom cell numbers and decreased the cell size, and this was caused by a strong increase in abundance of a few small species. The field study was sampled later in the season with lower general production and abundance. Still, the general decrease in cell size was apparent when comparing the front to the wake of the mussel reef, and this was caused by a change in species composition where a small diatom species (Navicula spp.) was more common in the wake of the reef, and one of the largest diatom species in the area (Pleurosigma aestuarii) prevailed in front of the mussel reef. At the same time, species richness and chlorophyll- $a$ concentrations in the biofilm in general correlated positively with the species composition of diatoms around the mussel reef. The size of diatoms determines growth and gross photosynthesis rates where smaller cells have a higher productivity (Geider et al. 1986; Morin et al. 2008), and earlier published results showed that the artificial mussel reefs increase chlorophyll- $a$ concentrations in the sediment (Engel et al. 2017). Thus, the small reefs mimicked and reinforced parts of the natural pattern in diatom community composition and function that we documented in the field, indicating that the natural intertidal shellfish reef has a significant impact on the function of the biofilm in the study area. The function of the intertidal biofilm provides large ecosystem services by stabilising the surface of coastal sediments and increasing sedimentation (Grant et al. 1986; Vos et al. 1988; Paterson 1989; Hoagland et al. 1993; Malarkey et al. 2015); improving water quality by binding toxic metals and pathogens (Decho 2000); contributing to coastal production (Colijn and de Jonge 1984) and sustaining the intertidal food-web (Christiaanen et al. 2017). This highlights the importance of intertidal shellfish reefs for intertidal ecosystems, supporting ecosystem functions and services for coastal populations by promoting the biofilm (Widdows and Brinsley 2002; van der Zee et al. 2012; Engel et al. 2017; Eriksson et al. 2017).

The experimental reefs were very small compared to natural reefs, and it is not clear how the small-scale experimental effects compare to the natural large-scale effects that mussel reefs have on their surroundings. Natural mussel reefs stabilise the sediment up to $100 \mathrm{~m}$ in the wake of their physical structures (Donadi et al. 2013a, b; van de Koppel et al. 2015). However, the species composition changed correspondingly when comparing small- and large-scale effects in the experiment: the artificial mussel reefs promoted smaller species, and the species were smaller in the wake of the mussel reef than on the sandy plain. Thus, the small-scale effect of the artificial mussel reef was similar to the large-scale effect of the natural mussel reef. The diatom community was, in general, dominated by small Navicula species, which is common for intertidal sediments in the Wadden Sea (Janssen et al. 1999). The sheltered wake of the mussel reef with less sediment erosion and more cohesive sediment was characterised by smaller species of diatoms (length $<10 \mu \mathrm{m}$ ) (Sabbe 1997), such as Nitzschia spp., Cylindrotheca closterium, and the smallest Navicula species. The sandy area, with high sediment erosion and more non-cohesive sediment, and the front of the mussel bed with strong hydrodynamic conditions, was characterised by larger species (mainly epipelon: length of $>10 \mu \mathrm{m}$ ), such as Pleurosigma aestuarii, Entomoneis paludosa, Stauroneis spp., and the largest species of Navicula. Earlier, field studies have highlighted the importance of sediment erosion for diatom community composition, suggesting that the adhesion capacity of the diatoms themselves and the sediment sorting (grain size) by hydrodynamic conditions determine the diatom assemblage structure (e.g. Colijn and Dijkema 1981; Sundbäck 1983; De Jonge 1985; Sabbe and Vyverman1991; Ribeiro et al. 2013). Diatom cell size affects attachment capacity, and exposure to wave action determines the size distribution of periphyton diatom communities on hard substrates (Busse and Snoeijs 2003). Accordingly, Delgado et al. (1991) showed that large diatom species were favoured in 


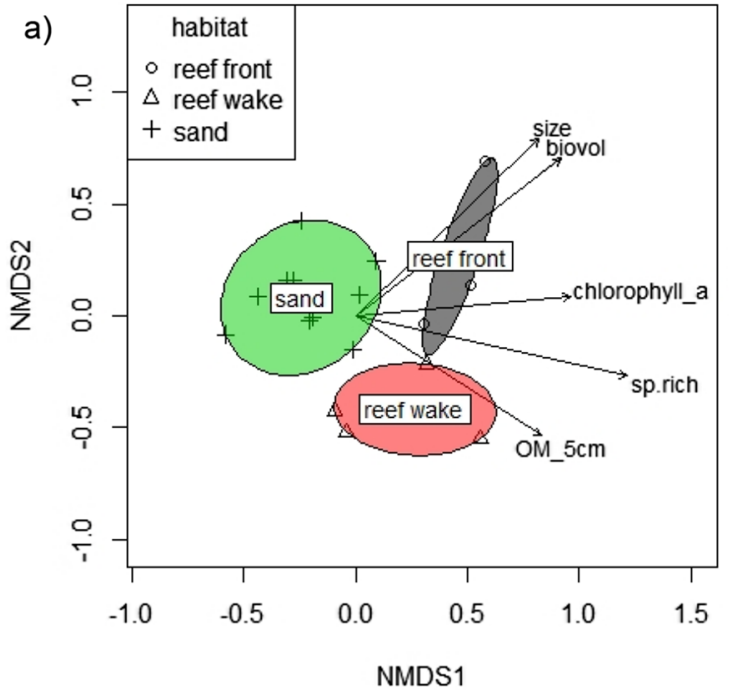

Fig. 2 Nonmetric Multidimensional Scaling (NMDS) results showing the $\mathbf{a}$ site and $\mathbf{b}$ species scores for the two first ordination axes. The ellipses are ellipsoid hulls that enclose all site scores of each habitat type (green: sand, red: wake of mussel reef, grey: front of mussel reef). The arrows show significant correlations with environmental and biological variables $(p<0.05)$. Abbreviations arrows: size average size of cells in the sample, biovol total biovolume of the sample,

exposed sandy substrates with strong hydrodynamic conditions, suggesting they were less vulnerable in a harsh sedimentary environment. Our study indicates that the physical protection against wave exposure provided by the formation of shellfish reefs creates a habitat favouring small motile benthic diatoms sensitive to sediment erosion.

The vertical migrating behaviour of the pennate diatom community that moves around in the top layer of the sediment is characteristic for intertidal flats (Colijn and De Jonge 1984; de Jonge 1985). The migrating behaviour is also important for the development of the microphytobenthos biofilm. Motility is linked to the occurrence of extracellular polymeric substances (EPS), which is exuded from their raphe, a slit in their silicate exterior (frustule) (Lind et al. 1997). The migration of diatoms is strongly promoted by light, and increasing light leads to an accumulation of diatom cells on the sediment surface (Sauer et al. 2002). The EPS exuded by migratory diatoms contributes significantly to the biofilm matrix (Stal and Brouwer 2003). There is a negative correlation between grain size and the amount of EPS in the sediment (Brouwer et al. 2003), and diatom biomass is, in general, higher in cohesive than in non-cohesive sediment (in cohesive sediment, the grain size diameter is less than $63 \mu \mathrm{m}$ ) (De Brouwer and Stal 2001; Kromkamp and Foster 2006); indicating that biofilms probably can only develop in sediment characterised by low energy (Stal and Brouwer 2003). This further supports the hypothesis that it is the sediment stabilising effect that enhanced

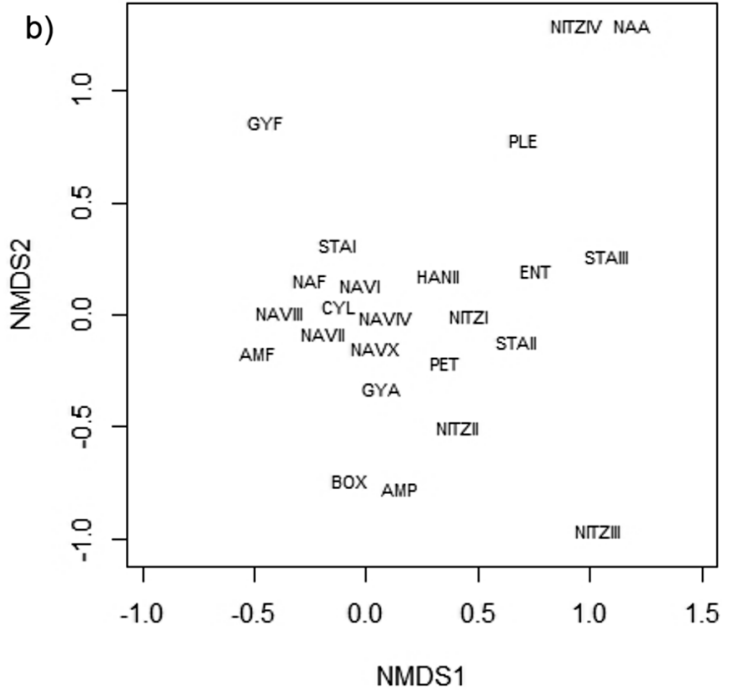

chlorophyll- $a$ chlorophyll- $a$ content in the top $2 \mathrm{~mm}$ of sediment, OM_5 organic matter content of top $5 \mathrm{~cm}$ of sediment, $s p$. rich number of species in the sample. The species scores are the weighted average of the site scores for each species along the ordination axes. The weighted average is constructed by weighing the biovolume of each species to corresponding value on the NMDS axes for each site. For abbreviations of species names, see Table S4

the biofilm development on the artificial and natural shellfish reefs in our study, shown by an increasing number of diatom cells or biovolume in the sediment.

The interaction between the biofilm and shellfish reefs indicates the importance of facilitative processes between individual organisms and organism groups in harsh environments with high abiotic stress, such as tidal flats (Maestre et al. 2009; Eriksson et al. 2010). By ameliorating hydrodynamic disturbance, blue mussel reefs facilitate the biofilm and thereby create regions with high microphytobenthos biomass and primary production (Donadi et al. 2013a, b; Engel et al. 2017; Eriksson et al. 2017, this paper). At the same time, because of resuspension, the microphytobenthos play a major part in benthic-pelagic coupling and contribute strongly to the production in estuaries and shallow coasts (Underwood and Kromkamp 1999). As such, the biofilm is important both for deposit and suspension feeding organisms (Jonge and Beusekom 1995; Ubertini et al. 2012), and an important food-source for the blue

Fig. 3 Composition of motile diatom species in samples collected from a sand flat, the wake of a mussel reef and the front of the same mussel reef, based on a biovolume, $\mathbf{b}$ number of individuals, $\mathbf{c}$ mean biovolume of the individual cells, $\mathbf{d}$ species richness of the diatom community, e chlorophyll- $a$ concentrations in the upper $2 \mathrm{~mm}$ of the sediment, and $\mathbf{f}$ the organic matter content of the upper $5 \mathrm{~cm}$ of the sediment. Error bars show standard error of the mean; in $\mathbf{a}$ and $\mathbf{b}$ the bars show SE for the total biovolume and the sum of all diatom cells, respectively. The legend on the top rank the species left to right from smallest to largest size. For abbreviations of species names, see Table S4 
-small cells $\square$ NAVII $\square$ NAVIII $\square$ HANII $\square$ NAVIV $\square$ NAVX $\square$ large cells $\square$ PLE
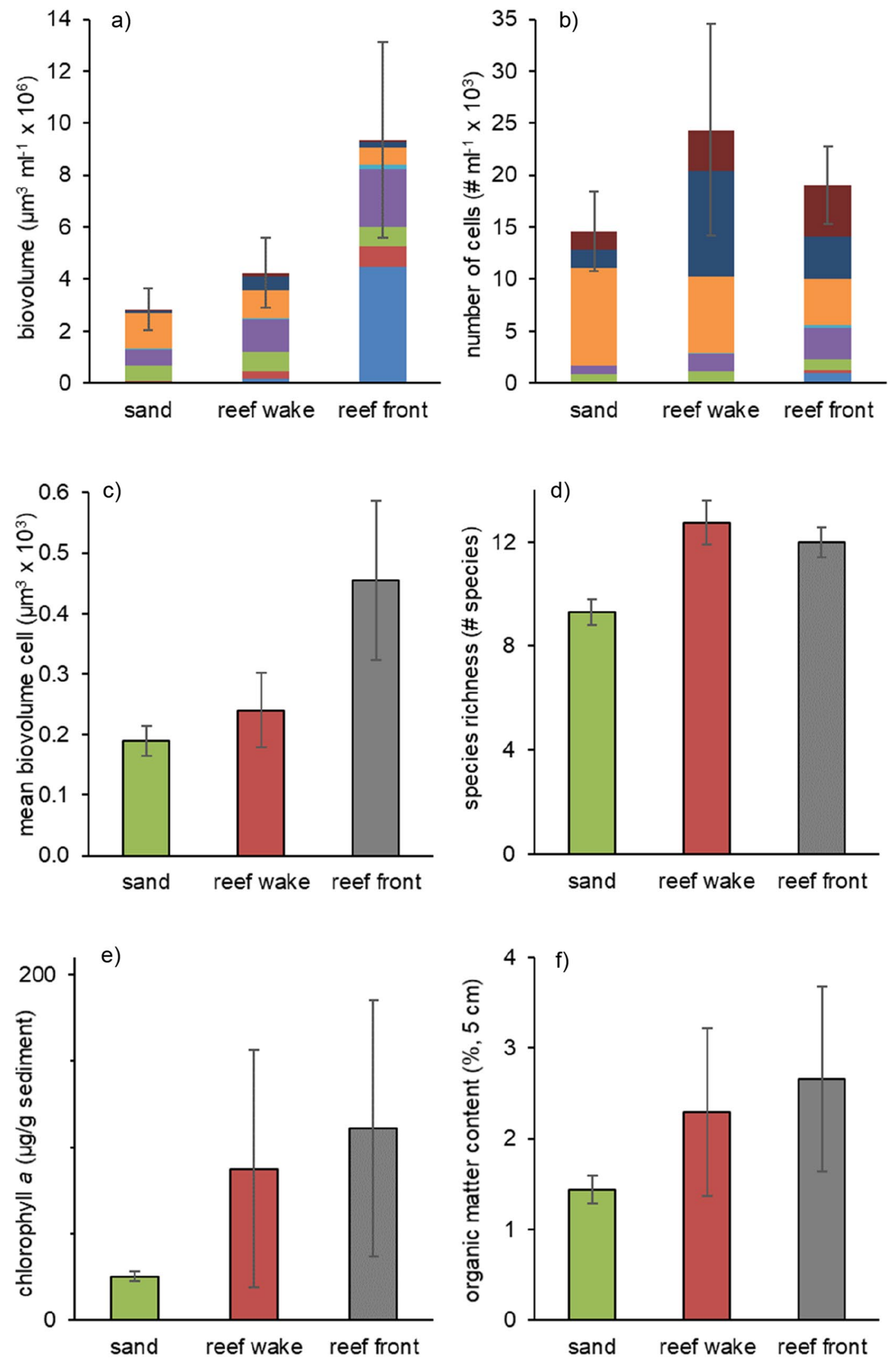
mussel reefs. Thus, our results strongly suggest that by initiating small-scale diatom sediment feedbacks, intertidal blue mussel reefs create areas of high production and biodiversity that they themselves are favoured by, potentially promoting also larger-scale self-reinforcing feedbacks.

Supplementary Information The online version of this article (https:// doi.org/10.1007/s00227-020-03819-2) contains supplementary material, which is available to authorized users.

Acknowledgements We thank Vereniging Natuurmonumenten and the Province of Friesland for granting us permission for field work on the tidal flats; Tjeerd Bouma at NIOZ for lending us his specially made Shear Vane for intertidal sediments; Javier Alegria, Luna van der Loos and Just van der Endt for their help in setting up the field experiment; and Stella Bos for help in the laboratory. This work was supported through a scholarship of the Indonesia Endowment Fund for Education to R. Andriana.

Author contributions The authors Rosyta Andriana (RA), Friederike G. Engel, Joao B. Gusmao, and Britas Klemens Eriksson (BKE) all contributed to the design and execution of the study and experiment; RA and BKE: did the statistical analyses and provided a first draft of the manuscript. All contributed to writing.

Funding This work was supported through a scholarship of the Indonesia Endowment Fund for Education to R. Andriana.

Availability of data and material All data generated or analysed during this study are available in the world data centre PANGEA.

\section{Compliance with ethical standards}

Conflict of interest The authors have no conflicts of interests or competing interests to declare.

Ethical standards This research was conducted in accordance with the Netherlands Code of Conduct for Scientific Practice. All applicable international, national, and institutional guidelines for sampling, care, and experimental use of organisms for the study have been followed.

Open Access This article is licensed under a Creative Commons Attribution 4.0 International License, which permits use, sharing, adaptation, distribution and reproduction in any medium or format, as long as you give appropriate credit to the original author(s) and the source, provide a link to the Creative Commons licence, and indicate if changes were made. The images or other third party material in this article are included in the article's Creative Commons licence, unless indicated otherwise in a credit line to the material. If material is not included in the article's Creative Commons licence and your intended use is not permitted by statutory regulation or exceeds the permitted use, you will need to obtain permission directly from the copyright holder. To view a copy of this licence, visit http://creativecommons.org/licenses/by/4.0/.

\section{References}

Admiraal W (1984) The ecology of estuarine sediment-inhabiting diatoms. In: Round FE, Chapman DJ (eds) Progress in phycological research, vol 3. Biopress, Bristol, pp 269-322
Aleem AA (1950) The diatom community inhabiting the mud-flats at Whiststable. New Phytol 49:174-188

Andriana R, van der Ouderaa I, Eriksson BK (2019) A Pacific oyster invasion transforms shellfish reef structure by changing the development of associated seaweeds. Estuar Coast Shelf Sci 235:106564. https://doi.org/10.1016/j.ecss.2019.106564

Asmus RM, Asmus H (1991) Mussel beds: limiting or promoting phytoplankton? J Exp Mar Biol Ecol 148:215-232

Barnett A, Méléder V, Blommaert L, Lepetit B, Vyverman W et al (2015) Growth form defines physiological photoprotective capacity in intertidal benthic diatoms. ISME J 9:32-45

Brouwer JF, Wolfstein CK, Ruddy GK, Jones TER, Stal LJ (2005) Biogenic stabilization of intertidal sediments: the importance of extracellular polymeric substances produced by benthic diatoms. Microb Ecol 49:501-512

Busse S, Snoeijs P (2003) Gradient responses of diatom communities in the Bothnian Sea (Northern Baltic Sea) with emphasis on responses to water movement. Phycologia 42:451-464

Christianen MJA, Middelburg JJ, Holthuijsen SJ, Jouta J, Compton TJ, van der Heide T, Piersma T, Sinninghe Damsté JS, van der Veer HW, Schouten S, Olff H (2017) Benthic primary producers are key to sustain the Wadden Sea food web: stable carbon isotope analysis at landscape scale. Ecology 98:1498-1512

Colijn F, de Jonge VN (1984) Primary production of microphytobenthos in the Ems-Dollard Estuary. Mar Ecol Prog Ser 14:185-196

Colijn F, Dijkema KS (1981) Species composition of benthic diatoms and distribution of chlorophyll on an intertidal flat in the Dutch Wadden Sea. Mar Ecol Prog Ser 4:9-21

De Brouwer JFC, Stal LJ (2001) Short-term dynamics in microphytobenthos distribution and associated extracellular carbohydrates in surface sediments of an intertidal mudflat. Mar Ecol Prog Ser 218:33-44

De Brouwer J, de Deckere GT, Stal LJ (2003) Distribution of extracellular carbohydrates in three intertidal mudflats in Western Europe. Estuar Coast Shelf Sci 56:313-324

De Jonge VN (1985) The occurrence of 'epipsammic' diatom populations: a result of interaction between physical sorting of sediment and certain properties of diatom species. Estuar Coast Shelf Sci 21:607-622

De Jong DJ, de Jonge VN (1995) Dynamics and distribution of microphythobenthos chlorophyll $a$ in the Western Scheldt estuary (South West Netherlands). Hydrobiologia 311:21-30

Decho AW (2000) Microbial biofilms in intertidal systems: an overview. Cont Shelf Res 20:1257-1273

Delgado M, de Jonge VN, Peleteir H (1991) Effect of sand movement on the growth of benthic diatoms. J Exp Mar Biol Ecol 145:221-231

Donadi S, van der Heide T, van der Zee EM, Eklöf JS, van de Koppel J, Weerman EJ, Piersma T, Olff H, Eriksson BK (2013a) Crosshabitat interactions among bivalve species control community structure on intertidal flats. Ecology 94:489-498

Donadi S, Weestra J, Weerman EJ, van der Heide T, van der Zee EM, van de Koppel J, Olff H, Piersma T, van der Veer H, Eriksson BK (2013b) Non-trophic interactions control benthic producers on intertidal flats. Ecosystems 16:1325-1335

Donadi S, van der Zee EM, van der Heide T, Weerman EJ, Piersma T, van de Koppel J, Olff H, Bartelds H, van Gerwen I, Eriksson BK (2014) The bivalve loop: intra-specific facilitation in burrowing cockles through habitat modification. J Exp Mar Biol Ecol 461:44-52

Engel FG, Alegria J, Andriana R, Donadi S, Gusmao JB, van Leeuwe MA, Matthiessen B, Eriksson BK (2017) Mussel beds are power stations on intertidal flats. Estuar Coast Shelf Sci 191:21-27

Eriksson BK, van der Heide T, van de Koppel J, Piersma T, van der Veer HW, Olff H (2010) Major changes in the ecology of the 
Wadden Sea: human impacts ecosystem engineering and sediment dynamics. Ecosystems 13:752-764

Eriksson BK, Westra J, van Gerwen I, Weerman EJ, van der Zee EM, van der Heide T, van de Koppel J, Olff H, Piersma T, Donadi S (2017) Facilitation by ecosystem engineers enhances nutrient effects an intertidal system. Ecosphere. https://doi.org/10.1002/ ecs2.2051

Geider RJ, Platt T, Raven JA (1986) Size dependence of growth and photosynthesis in diatoms: a synthesis. Mar Ecol Prog 30:93-104

Giles H, Pilditch CA (2006) Effects of mussel (Perna canaliculus) biodeposit decomposition on benthic respiration and nutrient fluxes. Mar Biol 150:261-271

Grabowski R (2014) Measuring the shear stress of cohesive sediment in the field. In: Clarke L (ed) Geomorphological techniques. British Society for Geomorphology, London, p 10

Grant JU, Bathman V, Mills EL (1986) The interaction between benthic diatom films and sediment transport. Estuar Coast Shelf Sci 23:225-238

Gutiérrez JLC, Jones G, Strayer DL, Iribarne OO (2003) Mollusks as ecosystem engineers: the role of shell production in aquatic habitats. Oikos 101:79-90

Heip CHR, Goosen NK, Herman PMJ, Kromkamp J, Middelburg JJ, Soetaert K (1995) Production and consumption of biological particles in temperate tidal estuaries. Oceanogr Mar Biol Annu Rev 33:1-149

Hillebrand H, Dürselen CD, Kirschtel D, Pollingher U, Zohary T (1999) Biovolume calculation for pelagic and benthic microalgae. J Phycol 35:403-424

Hoagland K, Rosowski R, Gretz MR, Roemer SC (1993) Diatom extracellular substances: functions fine structure chemistry and physiology. J Phycol 29:537-566

Janssen M, Hust M, Rhiel E, Krumbein WE (1999) Vertical migration behaviour of diatom assemblages of Wadden Sea sediment (Dangast Germany): a study using cryo-scanning electron microscopy. Int Microbiol 2:103-110

Jeffrey SW, Humphrey GF (1975) New spectrophotometric equations for determining chlorophylls $a b c_{1}$ and $c_{2}$ in higher plants algae and natural phytoplankton. Biochem Physiol Pflanzen 167:191-194

Kautsky N (1987) Role of biodeposition by Mytilus edulis in the circulation of matter and nutrients in a Baltic coastal system. Mar Ecol Prog Ser 38:201-212

Kromkamp JC, Foster RM (2006) Developments in microphytobenthos primary productivity studies. In: Proceedings: functioning of microphytobenthos in estuaries Royal Netherlands Academy of Arts and Sciences, pp 9-30

Lind J, Heimann LK, Miller EA, van Vliet C, Hoogrenradd NJ, Wetherbee R (1997) Substratum adhesion and gliding in a diatom are mediated by extracellular proteoglycans. Planta 203:213-221

Maestre FT, Callaway RM, Valladares F, Lortie CJ (2009) Refining the stress-gradient hypothesis for competition and facilitation in plant communities. J Ecol 97:199-205

Malarkey J, Baas J, Hope J et al (2015) The pervasive role of biological cohesion in bedform development. Nat Commun 6:6257

Morin S, Coste M, Delmas F (2008) A comparison of specific growth rates of periphytic diatoms of varying cell size under laboratory and field conditions. Hydrobiologia 614:285-297

Oksanen JF, Blanchet G, Friendly M, Kindt R, Legendre P, McGlinn D, Minchin PR, O'Hara RB, Simpson GL, Solymos P, Stevens MHH, Szoecs E, Wagner H (2019) Vegan: Community ecology package. R package version 2.5-6. https://CRAN.R-project.org/ package $=$ vegan

Paterson DM (1986) The migratory behavior of diatom assemblages in a laboratory tidal micro-ecosystem examined by low temperature scanning electron microscopy. Diatom Res 1:227-239
Paterson DM (1989) Short-term changes in the erodibility of intertidal cohesive sediments related to the migratory behaviour of epipelic diatoms. Limnol Oceanogr 15:159-168

R Core Team (2020) R: a language and environment for statistical computing. 2020. R Foundation for Statistical Computing, Vienna, Austria. https://www.R-project.org/

Ribeiro L, Brotas V, Rincé Y, Jesus B (2013) Structure and diversity of intertidal benthic diatom assemblages in contrasting shores: a case study from the Tagus Estuary. J Phycol 49:258-270

Sabbe K (1997) Systematics and ecology of intertidal benthic diatoms of the Westerschelde estuary (The Netherlands), 2 vol. $\mathrm{PhD}$ dissertation, Universiteit Gent, Ghent Belgium, p 347

Sabbe K, Vyverman W (1991) Distribution of benthic diatom assemblages in the Westerschelde estuary (Zeeland The Netherlands). Belg J Bot 124:91-101

Sauer J, Klaus W, Maier U, Rhiel E (2002) Effects of salinity light and time on the vertical migration of diatom assemblages. Diatom Res 17:189-203

Underwood GJC, Smith DJ (1998) In situ measurements of exopolymer production by intertidal epipelic diatom-dominated biofilms in the Humber estuary. In: Black KS, Paterson DM, Cramp A (eds) Sedimentary processes in the intertidal zone, vol 139. Geological Society London Special Publications, London, pp $125-134$

Staats N, de Deckere EMGT, Stal LJ (2001) Spatial patterns of benthic diatoms, carbohydrates and mud on a tidal flat in the EmsDollard estuary. Hydrobiologia 448:107-115

Stal LJ, Brouwer JFC (2003) Biofilm formation by benthic diatoms and their influence on the stabilization of intertidal mudflats. Ber FZ Terramare 12:109-111

Sundbäck K (1983) Microphytobenthos on sand in shallow brackish water Öresund Sweden. Doctoral dissertation, University of Lund, Sweden, p 209

Ubertini M, Lefebvre S, Gangnery A, Grangeré K, Le Gendre R et al (2012) Spatial variability of benthic-pelagic coupling in an estuary ecosystem: consequences for microphytobenthos resuspension phenomenon. PLoS ONE 7(8):e44155

Underwood GJC, Kromkamp J (1999) Primary production by phytoplankton and microphytobenthos in estuaries. Adv Ecol Res 29:93-153

Underwood GJC, Smith DJ (1998) In situ measurements of exopolymer production by intertidal epipelic diatom-dominated biofilms in the Humber estuary. In: Black KS, Paterson DM, Cramp A (eds) Sedimentary processes in the intertidal zone, vol 139. Geological Society London Special Publications, London, pp $125-134$

Utermöhl H (1958) Zur Vervollkommnung der quantitativen phytoplankton methodik. Mitteilungen Int Vereinigung Theoretischen Angewandten Limnol 9:263-272

Van de Koppel J, Gascoigne J, Theraulaz G, Mooij RMW, Herman P (2008) Experimental evidence for spatial self-organization and its emergent effects in mussel bed ecosystems. Science 322:739-742

Van de Koppel J, van der Heide T, Altieri AH, Eriksson BK, Bouma TJ, Olff H, Silliman BR (2015) Long-distance interactions regulate the structure and resilience of coastal ecosystems. Annu Rev Mar Sci 7:139-158

Van der Wal D, Wielemaker-van den Dool A, Herman PJ (2010) Spatial synchrony in intertidal benthic algal biomass in temperate coastal and estuarine ecosystems. Ecosystem 13:338-351

Van der Zee EM, van der Heide T, Donadi S, Eklöf JS, Eriksson BK, Olff H, van der Veer HW, Priesma T (2012) Spatially extended habitat modification by intertidal reef-building bivalves has implications for consumer--resource interactions. Ecosystems 15:664-673 
Verwey J (1952) On the ecology and distribution of cockle and mussel in the Dutch Waddensea, their role in sedimentation and the source of their food supply, with a short review of the feeding behaviour of bivalve molluscs. Arch Néerlandaises Zool 10:172-239

Vos PC, de Boer PL, Misdorp R (1988) Sediment stabilization by benthic diatoms in intertidal sandy shoals; qualitative and quantitative observations. In: Van Gelder A, Nio SD, de Boer PL (eds) Tide-influenced sedimentary environments and facies. D. Reidel Publishing Co, Dordrecht, pp 511-526

Widdows J, Brinsley MD (2002) Impact of biotic and abiotic processes on sediment dynamics and the consequences to the structure and functioning of the intertidal zone. J Sea Res 48:143-156
Widdows J, Brinsley MD, Salkeld PN, Elliot M (1998) Use of annular flumes to determine the influence of current velocity and bivalves on material flux at the sediment-water interface. Estuaries 21:552-555

Publisher's Note Springer Nature remains neutral with regard to jurisdictional claims in published maps and institutional affiliations. 